The son of Lieut.-Colonel B. H. Pollard, of the Indian Staff Corps, he thought at first of an Army career, but later studied medicine at St. Bartholomew's Hospital and King's College, London. Circumstances making it impossible for him to complete his medical training, he turned to engineering, which he studied at University College and (as an apprentice) at Siemens Bros. However, during his period at University College, he acted for some time as demonstrator and assistant to Prof. Karl Pearson, a contact which powerfully affected his thought and methods.

In 1911 Pollard joined the staff of Nobels Explo. sives, Ltd., and established a special physical laboratory at Croydon for this firm. He was presently given the post of chief physicist and superintendent of the firm's testing station, but on the outbreak of war in 1914 he was gazetted a second lieutenant in the Royal Scots Fusiliers (having previously held a commission in the militia forces). In 1918 he was appointed sub-director of the Instrument Section in the Ministry of Munitions (Aircraft Production) and was gazetted captain in the R.A.F. However, the exigencies of war had led to the formation of a Technical Optics Department at the Imperial College, under the directorship of the late Prof. F. J. Cheshire, and Pollard was appointed to the chair of instrument design, which he held until he reached the age of sixty-five. Even then he seemed to have lost little of his health and vigour, and until his death he was director and consultant to Messrs. Daniel Varney, Ltd. He was awarded the degree of D.Sc. (Engineering) in 1943. $\mathrm{He}$ was made a professor emeritus of the Imperial College and held numerous honorary posts of public importance.

Being extremely inventive and versatile, Pollard developed many instruments and appliances, including a new nephelometer, appliances for artificial limbs, reflector lights, an interchangeable nosepiece for microscope objectives, and many other things. $\mathrm{He}$ felt very strongly that instrument makers in Great Britain were dominated by ideals more appropriate to heavy engineering production than to scientific instruments, and he turned to the kinemat. ical theories of Clerk Maxwell as a satisfactory basis for reform. His views were expounded especially in his Cantor Lectures to the Royal Society of Arts in 1922, and in a book on "The Kinematical Design of Couplings in Instrument Mechanisms", published in 1929 by Adam Hilger, Ltd. He tried to show that instrument design is essentially a special subject and demands a discipline all its own. Although his chair at the Imperial College has not so far been filled, it may be claimed that his influence can be felt in such steps as the beginning of the new Department of Instrument Technology at the Northampton Polytechnic, London, and in numerous examples of moderm instruments in which kinematical principles are employed.

Pollard had essentially a tidy mind, and he loved card-indexes and files. His personal possessions were well catalogued; he did not keep his gospel merely for others. This trait was sometimes the source of quips by others with more haphazard methods'slovenly' was his most severe word of scorn, and there was unholy joy when on one occasion he was human enough to lose a library book. The Universal Decimal Classification made an instant appeal to him, and he not only became an enthusiastic advocate, but also contributed very materially to its develop. ment in the field of optics. He became the first president of the British Society for Intermational Bibliography in 1927, and took a leading part in the conferences of the International Federation for Documentation held on the Continent. A noteworthy address was on "A Proposed Plan for the Mobilization of the Bibliographical References to the contents of the World's Non-fiction Literature", in which there is a plan for National Bureaux of Information which might, working under an International Information Council, make (and keep up to date) complete U.D.C. indexes of human knowledge; for a student of a special subject might then obtain all the useful references to papers or books in his field simply by citing the appropriate classification numbers. $\mathrm{He}$ beheld with dismay human knowledge growing not only out of control but also out of reach. Like H. G. Wells, he believed in wisdom as contained in books, and wanted badly to make it accessible. He will be missed in an age in which such optimism is more rare, but at least he has helped us to grasp the magnitude of the problems involved.

Pollard had a wide circle of friends both in Great Britain and abroad, and was always willing to give time and attention to those who asked his help or advice. In 1915 he married Gabrielle, daughter of Mr. Frederick Urwick, and he leaves also a son and a daughter.

L. C. MARTIN

\section{Mr. G. J. Arrow}

WE regret to record the death on October 5, after a brief illness, of Gilbert John Arrow, late deputy keeper in the Department of Entomology in the British Museum (Natural History). Born on Decem. ber 20, 1873, the son of John Garner Arrow, of Streatham, Arrow was trained for the profession of architecture, but in 1896 entered the more congenial service of the British Museum (Natural History) at South Kensington. Here he was assigned to the study of beetles and early specialized on the Lamellicornia, upon which group he soon made himself an authority. His greatest work was the four volumes on the Lamellicorn Coleoptera of the Fauna of India series. He also contributed numerous papers, more than a hundred in all, to the Transactions of the Royal Entomological Society of London, the Annals and Magazine of Natural History, and other scientific journals.

Mr. Arrow retired under the age limit in 1938, but continued voluntarily his work at the Museum until within a few weeks of his death. This work was of untold value to the Museum, especially during the war years and the trying times that followed, and was recognized by the Trustees of the Museum by the bestowal upon him recently of the special distinction of 'honorary associate' of the British Museum. His imperturbability was immense; he would continue calmly at work during air-raid warnings, and even when found under a shower of glass when a flying bomb fell almost outside his window, his main concern was that he could not find his spectacles.

He was a great lover of music, and did much to encourage musical talent among the junior members of the Museum staff until increasing deafness made this no longer possible. He was also an expert photographer and would frequently use his own photographs in illustration of his papers.

He married in 1912 Miss Rachel Katharine Davis, who survives him, and to whom we would tender our sincere sympathy in her bereavement.

K. G. BraIR 